\title{
A Comparative Study of Derrida's Binary Oppositions in Escher's Day and Night Painting
}

Ashraf-o-Sadat Mousavilar

AL Zahra University, Tehran (Iran)

Sadaf Pourmahmoud

AL Zahra University, Tehran, Iran 



\title{
A Comparative Study of Derrida's Binary Oppositions in Escher's Day and Night Painting
}

\section{Un Estudio Comparativo de la Oposición Binaria de Derrida en el Día y la Noche de Escher}

\author{
Ashraf-o-Sadat Mousavilar \\ AL Zahra University, Tehran (Iran) \\ ashrafmousavilar@alzahra.ac.ir \\ Sadaf Pourmahmoud \\ AL Zahra University, Tehran, Iran \\ sadafpour.m@gmail.com
}

Fecha de recepción: 07 de octubre de 2020

Fecha de aceptación: 23 de noviembre de 2020

\begin{abstract}
This article aimed at conducting a comparative study of Derrida's binary oppositions theory in Maurits Escher's Day and Night painting, indicating the applicability of the functions of the theory to the visual artistic works. Binary oppositions are among the dominant principles of the material world. Undoubtedly, such oppositions cannot be without their reflections in human art, especially visual illustrations. Sometimes, art reflects these oppositions and contradictions as they are and depicts them in the form of symbols and signs. For the sake of the comparative study of Derrida's theory with visual arts, it was necessary to choose a seminal artistic work. Hence, the Day and Night painting by Escher was selected as the most opposing artistic work of the contemporary times. This is because the title, form, and content of this work have plenty of oppositions. The results of this study, conducted with the aid of comparative and analytical methods, show that the number of binary oppositions in this Painting reaches to 7 items. In terms of generalization to artistic functions, this includes form and performance (content and validity) binary oppositions, which are applicable to Derrida's theory.
\end{abstract}

Keywords: Jacques Derrida; Binary oppositions; Day and Night; Maurits Cornelis Escher; Implied meaning; Visual arts. 
A Comparative Study of Derrida's Binary... - A. Mousavilar \& S. Pourmahmoud

\section{Resumen}

Este estudio ha comparado la teoría de la oposición binaria de Derrida en "Dia y Noche" de Maurits Escher. Las oposiciones binarias son los principios dominantes del mundo material. Sin lugar a dudas, las oposiciones no pueden dejar de reflejarse en el arte humano, especialmente en las ilustraciones visuales. Para el estudio comparativo de la teoría de Derrida con las artes visuales, fue necesario elegir un indicador de trabajo artístico. Así, la pintura "Día y noche" fue seleccionada por Escher como la obra artística más opuesta de la época contemporánea, que muestra las funciones artísticas de la teoría en sintonía con las obras artísticas visuales. Esto se debe a que la forma y el contenido de este trabajo tienen abundantes oposiciones. Los resultados de este estudio, que se realiza mediante método comparativo y analítico, muestran que el número de oposiciones binarias en esta Pintura llega a 7 ítems e incluye contenido y oposición binaria narrativa y se puede ajustar con la teoría de Derrida en términos de generalización a funciones artísticas.

Palabras clave: Jacques Derrida; Oposición binaria; Día y noche; Maurits Cornelis Escher; Significado implícito; Artes visuales.

\section{INTRODUCTION}

Jacques Derrida, a French and originally Algerian Philosopher, has introduced plenty of challenges to the world, to the degree that Nicolas Roil, the contemporary theorist, called this century as Derrida's century (Daryab, 2010). He also entitled Derrida's philosophy as an earthquake that shakes humans' minds and constantly generates questions for them (Daryab, 2010). Binary oppositions are among the most important arguments that were prompted by Derrida and other constructionists. They have been proposed based on a philosophy that considers the foundation of existence on the basis of binary oppositions. Derrida has made fundamental changes to the Western thinking and therefore the concept of binary oppositions (Meghdadi, 1999, p. 8). According to Derrida, philosophical-scientific thoughts exist in bipolar confinements in the infrastructure of Western thinking and act based on binary oppositions.

Art has an expressive formulation that can offer stories or interpretations in conjunction with real life incidents and can illustrate the truth with many contrasts. One of the most popular tendencies of the modern illustration artists is to create visual illusions and create ambiguous images. Visual illusions include images that are interpreted by the brain in a different way from what exist in reality. This approach has been used by different artists with different techniques. Among them binary oppositions are the most important techniques that have had a tremendous impact on the flow of illustration in the contemporary era. Understanding of binary oppositions requires a more detailed examination of such artistic works. The authors here focus on the binary oppositions in visual arts and evaluate them by analyzing and expressing their implied meanings. Moreover, the authors aim at creating and understanding binary oppositions in the designs and concepts of works from a new angle, that is, applying the binary oppositions theory of Derrida. 
Maurits Cornelis Escher (Jan 17, 1897- Mar , 1972) was a graphic artist from the Netherlands, who has created wonderful artistic works on wood and in lithography and contrast creating. His works were inspired by mathematical calculations. Escher is one of the optical art (Op Art) artists. Op Art can be called the art of the $20^{\text {th }}$ century. The artists in this style use color and contrast to create field depth sense, mobility, and volume in their works. In other words, they apply their skills and control on color and apply lines to create portraits that deceive the eyes of the prospective audiences. In the works of Escher, certainty and absolute concepts seem to be meaningless. He used binary oppositions and challenged their originality in his works. Escher's paintings are the result of smart use of unlimited types of potential facilities to provide world of objects beyond the order of the regularity of the ordinary situations (in our eyes).

The form and content of his works had plenty of oppositions, that is, his works were full of opposing values in terms of form, expression, structure, color, images, motifs, and illustrations. With this end in view, the research questions that prompted this study dealt with the amount of applicability of the theory of binary oppositions of Derrida to visual illustration works, and how its visual functions should be analyzed.

\section{THE MEANING OF THE TERM "OP ART”}

Op art, short for optical art, is a style of visual art that uses optical illusions. Op art works are abstract, created in black and white colors. Typically, they give the viewer the impression of movement, hidden images, flashing and vibrating patterns, or of swelling or warping. Op art was the prevalent art style of the 1960s, in which geometric elements were used to induce mental images that were based on creating visual errors.

\section{VISUAL ILLUSION OR OPTIMAL ILLUSION}

The mind of living beings, after seeing an object and based on the previous experiences, can add some concepts to the images that are created on retina. Some phenomena are visual, and due to this feature they can decrease the connection between the image in the retina and what is seen. These are in fact visual or optical illusions. They appear in opposition with physical reality, and as a result are manifested as an ordinary things in our eyes (Noroozitalab \& Rostami, 2012, p. 85).

Art has an expressive structure, which can supply a story or interpretation with regard to real life and claim for expression of a truth with lots of oppositions. In works of some artists, the senses seduce us to make mistake in getting the message, or it might be our mind that is deceiving us in perceiving what the real message is. In fact, both positives and negatives simultaneously play the role of form and context (Rahbarnia, 2019). Most of the times in daily life, such visual cases have been been 
appeared, or they have been found as puzzle form entertainments. Visual illusion includes images that are interpreted by the brain as different from the reality.

Binary oppositions are among the most important used tricks that have had deep impacts on the illustration processes of the contemporary times. Therefore, it is necessary to make more detailed analyses of artistic works to understand them. The researcher in the present article focused on the binary oppositions in Escher's Day and Night painting. By analyzing this work and expressing its explicit and implied meanings and how binary oppositions are created and understood in this masterwork, the researchers looked at such binary oppositions from a new perspective, that is, comparison with Derrida's binary oppositions theory.

\section{LITERATURE REVIEW}

Looking into the literature of related research, the researchers here found no work with the exact title of this study. Moreover, through searches on the internet, no similar study has been found, except for a thesis conducted by Masoumeh Habibie Afratakhti from Al-Zahra University (2014) under the title of "binary oppositions in Al-Lail Surah." The study presented the binary oppositions in Al-Lail Surah of Holy Quran and its artistic functions. The current study, therefore, is a pioneering one in terms of its theme, that is, comparative investigation of Derrida's binary oppositions theory in in Escher's Day and Night Painting with no similar counterpart in the literature.

The Theoretical framework of this study is based on the determination of the functions of binary oppositions in visual arts and using the language of philosophy of Derrida's binary oppositions for the transfer of the concepts expressed in visual works.

\section{CONCEPTUALIZATION OF BINARY OPPOSITION}

The concept of taghabol (opposition) in Dehkhoda Dictionary: confrontation, encountering, and getting together.

The term "sematic opposition" can be used as the opposite conceptual meaning of words. However, in semantics, the term confrontation is used instead of opposition (Habibie Afratakhti, 2014, p. 14).

\section{BINARY OPPOSITIONS}

Binary oppositions are categorized under the category of semantic opposition (Ahmadi, 1992, p. 398). In English, binary means dual. This term was used by the Russian morphologist Nikolay Sergeyevich Trubetskoy (1890-1938) for the first 
time (Schulrez, 2004, p. 51). Trubetskoy introduced it as the main foundation of hierarchical values, rooted in cultural history. The term can be considered a key concept in linguistics, semiotics, and literary criticisms. Binary oppositions in literary criticisms is one of the fundamental concepts underlying construction and post construction (Déconstruction) (Habibie Afratakhti, 2014, p. 25). In construction philosophy, the majority of concepts have been created based on binary oppositions. Constructionists believe that the nature and real origins of things are not in the things themselves, but in relations created among them that are then perceived by us.

\section{DERRIDA'S BINARY OPPOSITIONS}

Derrida's binary oppositions are among the postmodern theoretical paradigms called post construction, emerged in response to constructionism in the 1980s. In this paradigm, meaning is unclear and implies plurality for each effect. In this way, meaning is infinite in deconstruction, and is called the door of science and open revelation. It should be noted that in practice two situations can arise in this regard. In the first one, meaning may be inferred from the material presented in the appearance of the text. In the second one, according to the construction method, which focuses on binary oppositions, the structure is broken down, which is essentially the method of deconstruction. Here it is believed that the hierarchy between binaries, for example, good and evil and right and wrong must be eliminated, and a new hierarchy should be considered, so there is no certainty of meaning here (Shamisa, 2004, p. 190).

In deconstruction philosophy, a critical attitude exist towards these oppositions and the first concern of deconstruction is the system; not as destroying it, but opening the constructional facilities [...] deconstruction is a thinking over the system (Brannigan, 1999, p. 69). According to Derrida (1930-2004), the traditional logic has been polluted with opposition and dominance. Hence, through challenging the past opposition logic, Derrida tried to present logical expressions for philosophical discussions. This was underlying the philosophical design of deconstruction. With the deconstruction theory in the first edition of his Grammatology book, Derrida destroyed all foundations of the Western thinking. Some consider his theories as thinking terrorism, while some others consider it as liberal policy of difference, freedom, and personal choice (Bradley, 2008, p. 2).

According to Derrida, deconstruction happens since the signs never achieve final signifiers, and the meaning can be always observed nearby us while we cannot achieve it. Derrida collapses the hierarchy of oppositions, which has determined our recognition until now and considers this as the first strategy in deconstruction. This is not conducted according to a mechanical and formulated procedure since if pursued this way, another opposition would arise, which is the opposite state of the first one. Deconstruction cannot limit itself or make neutralization immediately; it will collapse the cliché oppositions by means of binary gestures, knowledge, and 
writing and generates a kind of general substitution in the system (Derrida, 1982, p. 329). In this regard, Derrida mentions that it is essential for us to think from now on in such way that there is no center anymore; center can be imagined in form of the current existence and reality. This is because it has no natural and fixed position, but it is a performance, a kind of displacement, in which countless semantic and sign replacements occur (Derrida, 2005, p. 353).

Moreover, Derrida emphasizes the undecidability of inferences: By uncertain range we mean the range in which the border between binary oppositions such as truth and virtue, dead and live, existence and nature, sign and signifier, speech and writing, and so forth appear, and it would be impossible to separate them [...] By using uncertain realm, Derrida denies the logical system of Aristotle, Hegel, and binary oppositions of constructionists (Zamiran, 2000, p. 110). The only conclusion of deconstruction among all deconstruction discussions is that there is no start point to achieve absolute goodness or absolute evil and the two concepts can be substituted (Zibakalam, 1999, p. 308). Binary oppositions of Derrida can be one of the postmodern theoretical paradigms called post-construction, emerged in response to constructionism in the 1980s. In this paradigm, meaning is uncertain. This paradigm considers semantic plurality for each work. Hence, meaning in deconstruction is infinite, and the doors of discovery are open in science, and there is no semantic certainty (Shamisa, 2004, p. 190-191).

\section{CONCEPTS OF BINARY OPPOSITIONS IN VISUAL ARTS}

The issue of opposition is one of the highlighted issues in many branches of knowledge such as logics, linguistics, philosophy, psychology, and so on. Brilliant thinkers have proposed views concerning opposition in each of these fields. Among the scientists before Socrates, Flavius Heraclius is the first person who referred to the issue of opposition in existence and its importance and considered it as the origin of life (Haling Dill, 2008, p. 97-98). After him, Plato (ibid, 110) and later Georg Wilhelm Friedrich Hegel, the German Philosopher (ibid, 205-220), and Jung also paid attention to role of oppositions in existence.

Oppositions are among the dominant principles of the material world, and human beings are combined of body and soul. Certainly, oppositions cannot be without reflections in human art, especially visual illustrations. Art sometimes reflects the oppositions as they are and portrays then in the form of symbols and signs. Andre Breton, the French poet and theorist (1896-1996), summarized the illustration as getting the inconsistencies together (Gharib, 1999, p. 39). Ezra Weston Loomis Pound, the American critic and poet (1885-1972), believes that illustration is not the sheer transfer and drawing of painting; illustration emphasizes the collection of thoughts and far emotions (ibid: 152). In view of some other critics, oppositions 
can be regarded as artistic illustrations just in the form of paradox or ambiguity and opposition. However, oppositions in artistic works always do not mean contrast. They sometimes complete each other in some works and make meaning alongside.

Based on the principles of oppositions, no sign can gain meaning by itself; its value can be defined by its relation with other signs (Sojudi, 2003, p. 25). Meaning is derived from the differentiation of signs that are categorized into two types (Chandler, 2008, p. 127):

a. Coordination (how to place elements together)

b. Replacement (how to replace elements with each other)

One way for success of the artist is to discover the interactive and oppositional relations in the real world or create such relations with the aid of expressive tricks such as contrasts or cooordination. Opposition in artistic signs is one of the instruments used by artists to express and transfer the meaning and concept. Moreover, this can introduce the artist as a clever, sensitive, and curious person, who notices the relation between elements and phenomena of the real world clearly and applies them in his/ her art.

\section{THE RELATION BETWEEN MEANING AND VISUAL ILLUSTRA- TIONS}

Visual illustrations and meanings have various relations. The most important relation between them is the relation of synonymy and contradiction, explained as follows:

Synonymy: commonness of different illustrations with a unit meaning such as images of a human and a man;

Contradiction: means that every illustration is pictured for a special meaning such as the image of a bird, book, house, sun, and so forth.

\section{Explicit and implied meanings}

The meanings of words in a dictionary often involve the explicit implication of the words. For example, Ervin Panofsky, a researcher in the history of European art, argues that the explicit implication in images and in general of visual arts is the same meaning that all individuals generate in dealing with that effect in their minds (Zamiran, 2004, p. 119). On the contrary, implied meaning is a term used to describe the cultural meanings associated with a phrase. In terms of visual arts, the extension of a meaning to an image, the role of a work or even itself, the effects and 
characteristics and attributes of action, content and narrative, and factors such as social class, age, gender, ethnic belonging, and ethnicity of the audience are involved in the formation of implied meanings. Signs are polysomic in nature. In other words, they can be interpreted and paraphrased (ibid: 120).

In artworks where oppositions are used, the elements within the works do not have the same implications and explicit meanings in the outside world. The artist, with the aid of technical and visual capabilities, can define his purpose and use the language of the sarcasm and hints in his art. The current study presents a description of the most fundamental semiotic concepts and binary oppositions in visual arts in order to help us understand its applications in semiotic art studies.

Analysis of binary oppositions in the cognitive semantics of visual arts is based on the analysis of motifs. The semiologist can never find a sign in isolation and in a space. This refers to the point that sign is an indication beyond the codes that made it possible or from the work in which the actual realization was found and became a layer of it. The semiologist constantly deals with the motifs, and by entering into the field of study, the mechanisms of code are also noticed through motifs. Binary oppositions of motifs in an intuitive artwork are the result of the combination of different layers of signs that have been made possible by the operation of multiple codes.

The codes make the meaning of the work possible, and the meaning in the motifs constantly collapses and forms the other codes. Visual illustrations are physical phenomena, in the sense that they are understood by visual senses but are not definitive because they continuously and potentially may coincide with one role in another paradigm and take an important implication when viewed. There is no doubt that, depending on the artwork, some of the features of the motif in the binary oppositions, or even sometimes a feature, are more important than other features. Such features are considered more fundamental and have a steady presence in different manifestations; moreover, other layers of the motifs vary and may sometimes be more marginal. But it should be noted that the fixed layer of motifs, which motifs take their meaning from, are not superior to each other, but equal.

So an artwork has a sustainability aspect only within its boundary, meaning that every concrete communication action is formed according to its constituent motifs. This is why it is open and not closed, and it can be obtained from every feature with various meanings. The features in the binary oppositions are considered as the focal point of meaning that have a special place, and opposition motifs are merely marginalized as explicit meanings. In this sense, for example, in a bird artistic work, it is a bird, and this is a semantic and objective role to the margin, but its features are its opposites, its contrasts in color, form, context and lines, which create a special meaning in that bird and thus create special feelings and various meanings for different viewers. 
In fact, these binary oppositions are in the characteristics of motifs that produce meaning, and the role itself is a constant and explicit symbol everywhere. In binary oppositions, the bird, if placed in a work of art in black, is in contrast to another bird that is in the same work and is in white. This creates opposite meanings that no longer mean bird, but it can mean the meaning of day and night, death and life, oppression and peace, and many other meanings, which will mean rebirth and will serve as a sign of another sign. This process will continue indefinitely.

In fact, when an element of the so-called visual features of credibility is implied, it becomes meaningful and becomes layers of meaning in works, which duo to having codes, contains implicational worth. The characteristics of a visual effect produce and convey the meaning and message, which like a code involve the implications of that meaning and "the opinion of a semiologist, the concept of art, as in any other sense, in terms of opposition and relative system against the no-art, makes sense" (Sojoudi, 2012, p. 67). The paradigm of motifs in visual images with its opposition motifs creates an image. The layers and features add a new value to the motifs. It is a paradigm of the artist's creative and unique activity, and the semiologist of a work of art is one who can understand and interpret an artwork and does not designate signs as separate elements with values of motifs.

\section{Types of binary oppositions in visual arts}

The use of oppositions in the artwork makes it more meaningful and more powerful to show feelings, and thus translates concepts and messages more effectively and deeply. This is while lack of using the oppositions in qualities and influential elements usually causes unevenness and instability in the effect and lack of attractiveness of the effect. Oppositions in nature tend to sensitize our sense of power. Without cold, there is no heat, and without bitterness, there would be no sweetness. Coordination and opposition are against each other and they are of great importance. In visual arts, the concept of opposition involves several types and forms, and the sensory quality is due to the interaction of two or more opposing features of the elements of the images, which increases the power of visual expression.

Thus, the visual emphasis becomes more equitable and easier to communicate with, while these oppositions are closely interconnected and can only be understood together. The most important oppositions are: contrast in darkness and light, context, color, direction, positive and negative spaces, the parts and the whole, vertical and horizontal lines, diagonal and intersecting, and rhythm.

In the visual artwork, there are two types of binary oppositions:

- Form that include point, line, dark light, color, main field or background, composition, texture, symmetry and direction. 
- Content and narrative that include fragmentation and continuity, presence making and absence making, contraction and expansion, unity and dispersion, plurality and exaggeration, energetic and calm, implicit and explicit, impartiality and emphasis, agreement with reality and deviation from reality, single-elemental and multi-elemental, clear, fade, and narrative, which are caused by binary oppositions in the form of the work.

\section{FORMS OF GONTRADICTING ILLUSTRATIONS}

The meaning of contradicting illustrations varies depending on the number of various illustrations. Before defining oppositions in visual arts and categorizing their types, it is necessary to provide a short definition of the types of contradicting illustrations to clarify their status. Forms of contradicting illustrations are:

1. Similar

2. Opposite

3. Contradictory

a) Similar illustrations: when two illustrations are common in a unit reality; for example, pigeon and eagle, which are both birds, but regardless of their commonness in being a bird, they have two different roles to be pictured in terms of innate traits;

b) Opposite: two illustrations with opposite features, which can be placed in a unit picture such as sky/earth and sun/moon. For example, consider two images of man and woman. The two images are common because of their common point in being a human, although they are different in terms of their gender and their features. Therefore, opposition is against similarity, and this is a kind of contradiction. It means that in opposite image, under conditions that there exist a common point between them from one aspect and difference from another aspect, they are opposite;

c) Contradictory illustrations: two images with two different meanings that cannot be integrated in a common place and in a unit time like day and night.

\section{TYPES OF BINARY OPPOSITIONS}

Binary oppositions reflect various types and forms as follows:

1) Supplementation binary opposition: For example, in the pair "odd and even", if something is odd, it is not even for sure and vice versa (Asher, 1994, p. 138). 
2) Contradictory binary opposition: In this type of opposition, proving a negative word can make another word necessary. However, that word is not necessarily true; e.g., if something is hot, it is not cold for sure. However, if it is not cold, it is not hot necessarily (ibid, 138).

3) Diametrically binary opposition: In this type of oppositions, two words are in direct relations, so proving one word can necessitate the existence of the other one.

4) Active binary opposition (Content and Narrative): In a variety of visual phenomena, meaning does not exist only in images and simulated information of reality or codes, symbols and language, but it can be used to mean the contrast between traits, attributes, and techniques in the visual representation of a motif in the work. Compositions of the components and the hidden narrative of the work are also found here. In terms of components, phenomena such as color, context, dimension, ratio, and their relationships to the overall meaning of the work are different, and these various techniques are utilized in the visual representation of the contrast between the active properties (content and narrative) of a work. Table 1 depicts the most important Types of binary oppositions that can be easily understood and recognized by the viewers:

Table 1: Types of binary opposition of active Characteristics in Visual Arts

\begin{tabular}{|cc|}
\hline Presence making & Absence making \\
\hline Expansion & Contraction \\
\hline Dispersion & Unity \\
\hline Mobility & Calmness \\
\hline Explicit & Implicit \\
\hline Impartiality & Emphasis \\
\hline Deviation from the reality & Agreement with reality \\
\hline Single-elemental & Multi-elemental \\
\hline Diversity & Coherence \\
\hline Fading & Clarity \\
\hline Dissociation & Continuity \\
\hline Laconic & Exaggeration \\
\hline
\end{tabular}

5) Directional, linear, and diametrical binary oppositions: In directional type of binary opposition, examples such as "up/down", "coming/going", "arrive/ leave" can be mentioned. Common features of these pairs are that the pair members move based on special direction in one or two opposite directions. The movement may be towards up and down, left or right, or back or forward (Lyons, 1981: 281). 
For linear and diagonal examples, examples such as north/south, west/east or left/right, up/down can be named whose members are linearly opposite (e.g., north with east and west or right with up and down). When they are diagonally in conflict, they can be considered diametrically opposite. Therefore, north is in diametrical opposition with south, and east is in diametrical opposition with west, and up is in diametrical opposition with down (ibid, 282-283).

\section{THE DAY AND NIGHT PAINTING BY MAURITS CORNELIS ESCHER}

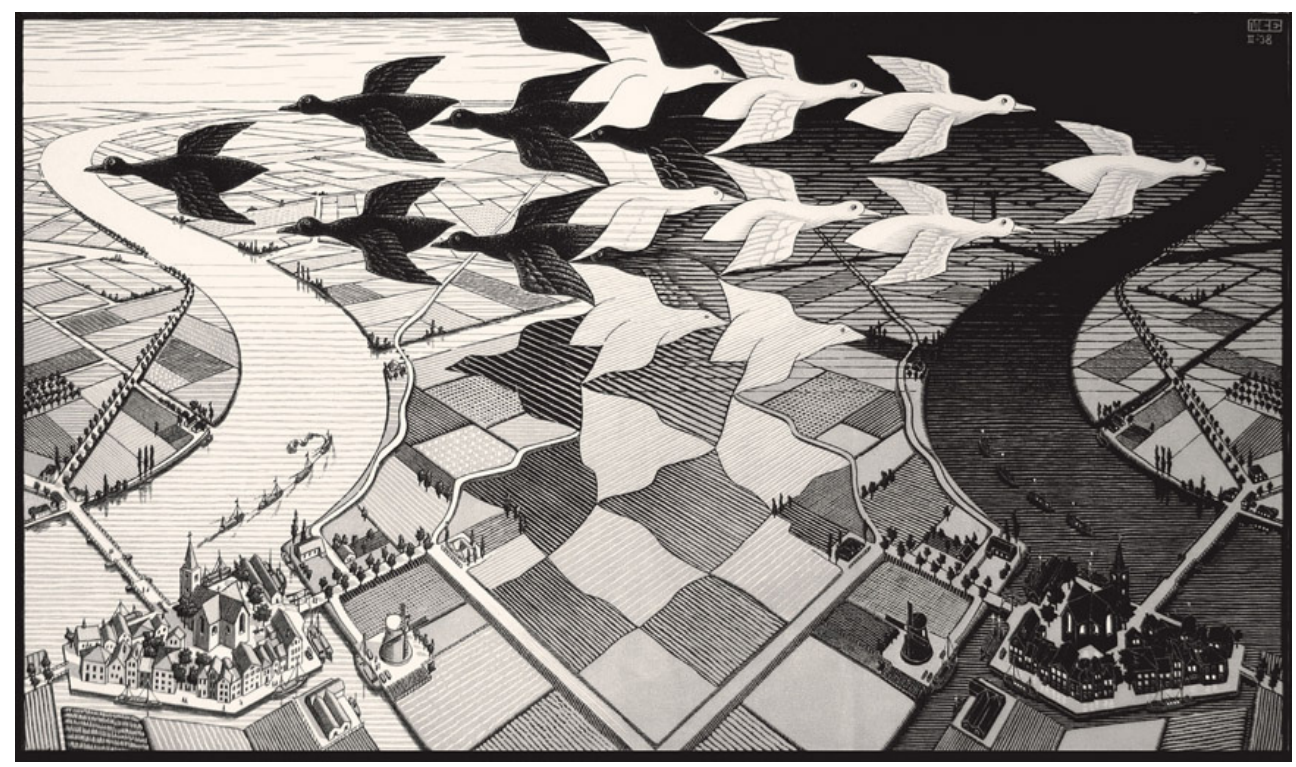

Figure 1: Day and Night by Maurits Cornelis Escher (Houle, 1998, p. 26)

\section{VISUAL STRUGTURE OF THE DAY AND NIGHT PAINTING}

Day and Night is a beautiful gravure by Maurits Cornelis Escher, which is illustrated in 1938 with wooden engraving using two horizontal frames in size of 6*39cm. This painting was among the works of Escher after the year 1937 (second group of artistic works of the artist) at the same time with deformation in his lifestyle and can be placed in the realm of illustrations with black and white contrast. These illustrations are completely similar in terms of form and direction even with differences of black and white color, and they can be adjusted with each other with eliminating the distance between a white and a black illustration and change in black color to white and vice versa. Escher used many types of visual illusions in this work. These include change in size and distance of objects and repetitive destruction of spatial dimensions from 2-D to 3-D and vice versa, which cause multiple interpretations in the minds of viewers, called the ambiguity deception. 
Among the visual structures of the painting are gray squared grounds going upward, changed into black and white motifs of birds. Black birds fly to the left, and white birds fly to the right side in opposite styles. In the left side, white birds move together and become one to form the sky and day perspective. In the right side, black birds are integrated and form the night. The day and night perspectives are mirror of each other, unified by gray ground, and again birds come out from them (Escher, 2010, p. 9). This work among Escher's works has illustrations with black and white symmetry, which can be adjusted on each other from the vertical axis. This work is grouped under the mirror works. One of the most important things in the Day and Night painting is its use of similar elements. According to Dandis (2016, p. 63) similar elements in visual language attract each other and dissimilar things dispose each other.

In this painting, similar to many other works of Escher, the mysterious space and the world of illusion and ambiguity can be found. According to L. Teober, these spaces are reflections of an important characterizing feature of our time, and Escher presented it in the most effective way through art (Teober, 1974, p. 2). In this painting, mysterious sadness and loneliness can be felt in the conflict of endless opposition with freedom and happiness among high energy forms and the elegant and static forms. The relations of directions and lines with each other and with conflicting directions and lines are pictured wonderfully, and the opposition of these forms can show the hidden conflict more and more.

\section{BINARY OPPOSITIONS IN DAY AND NIGHT PAINTING}

Binary oppositions derived in the work include:

1. Day and Night

2. Black and white colors

3. Sky and earth

4. Positive and negative patterns

5. Directions of movements towards right and left

6. Surface and volume in picture representation

7. Performance features (content and validity) including discretion and continuity, presence making and absence making, contraction and expansion, unity and dispersion, summarizing and exaggeration, fast and calm, implicit and explicit, impartiality and emphasis, agreement with reality and deviation from reality, single elemental and multi-elemental, and clear and fade.

The binary oppositions derived can be placed in two general types of binary oppositions in visual arts: 
1. Formal binary oppositions including point, line, dark, light, color, main range or background, composition, context, symmetry and direction, which can be observed in visual dimensions. These create binary oppositions including day and night, black and white, sky and earth, positive and negative illustrations, direction of right and left movements, and surface and volume in image representation.

2. Performance features oppositions (content and validity), which are created from binary oppositions in work's form. They show that meaning does not only exist in images and simulated information of reality or code, symbols, or languages, but in the opposition of traits, different techniques in visual expression of an illustration in work, and composition of the components and hidden massage of the work. The creator of the artwork intends components such as color, context, dimension, ratio, and their relations in composition with the total meaning of the work. These different techniques in visual expression encompass the opposition of performance features oppositions (content and validity).

Integration of the binary oppositions in this work follow certain movements. The communication of the movement begins from the creation of relationship between the audience and the illustration, actualized and believed in insight of day and night opposition. Table 2 depicts each of these binary oppositions based on classification and analysis of binary oppositions in visual arts by Mousavilar and Pour Mahmoud (2019). Accordingly, two formal and performance types of binary oppositions are adjusted with visual nature of contradicting illustrations in terms of point, line, darkness and light, major range or background, context and color. Moreover, the semantic oppositions include direction, symmetry, composition, positive and negative spaces, whole, part, and rhythm in visual arts. 
Table 2: types of binary oppositions of Day and Night painting by Escher. part 1 (source: author)

\begin{tabular}{|c|c|c|c|c|c|}
\hline \multirow{2}{*}{$\begin{array}{l}\text { Binary } \\
\text { oppositions of } \\
\text { day and night of } \\
\text { Escher }\end{array}$} & \multicolumn{5}{|c|}{ Types of binary oppositions of Day and Night of Escher } \\
\hline & illustrations & $\begin{array}{l}\text { semantic } \\
\text { opposition }\end{array}$ & $\begin{array}{l}\text { opposition of } \\
\text { darkness and } \\
\text { light }\end{array}$ & $\begin{array}{l}\text { context } \\
\text { opposition }\end{array}$ & $\begin{array}{c}\text { color } \\
\text { opposition }\end{array}$ \\
\hline Day and Night & $\begin{array}{l}\text { Inclined } \\
\text { illustration, } \\
\text { Opposite } \\
\text { illustrations }\end{array}$ & $\begin{array}{l}\text { Complementary } \\
\text { opposition }\end{array}$ & $\begin{array}{l}\text { Increasing and } \\
\text { decreasing } \\
\text { light, farness } \\
\text { and nearness of } \\
\text { lines, using dark } \\
\text { and light colors }\end{array}$ & $\begin{array}{l}\text { Opposition } \\
\text { of soft and } \\
\text { rough context, } \\
\text { dark and light, } \\
\text { low and high, } \\
\text { density of lines, } \\
\text { and direction of } \\
\text { right and left }\end{array}$ & $\begin{array}{l}\text { Contradictory } \\
\text { and } \\
\text { supplementary } \\
\text { opposition }\end{array}$ \\
\hline Black and white & $\begin{array}{l}\text { Opposite } \\
\text { illustrations }\end{array}$ & $\begin{array}{l}\text { Contradicting } \\
\text { opposition }\end{array}$ & $\begin{array}{l}\text { Using light and } \\
\text { dark colors }\end{array}$ & $\begin{array}{l}\text { Change in } \\
\text { density and } \\
\text { composition } \\
\text { of lines of left } \\
\text { and right in } \\
\text { opposition } \\
\text { to context of } \\
\text { colorful points }\end{array}$ & $\begin{array}{l}\text { Contradicting } \\
\text { and } \\
\text { supplementary } \\
\text { opposition }\end{array}$ \\
\hline Sky and earth & $\begin{array}{l}\text { Inclined } \\
\text { illustrations, } \\
\text { contradicting } \\
\text { illustrations }\end{array}$ & $\begin{array}{l}\text { Supplementary, } \\
\text { directional, } \\
\text { and diagonal } \\
\text { opposition }\end{array}$ & $\begin{array}{l}\text { Increasing and } \\
\text { decreasing light, } \\
\text { farness and } \\
\text { nearness of lines }\end{array}$ & $\begin{array}{l}\text { Change in } \\
\text { density of lines, } \\
\text { opposition of } \\
\text { diagonal and } \\
\text { horizontal lines }\end{array}$ & $\begin{array}{l}\text { Supplementary } \\
\text { opposition }\end{array}$ \\
\hline $\begin{array}{l}\text { Positive and } \\
\text { negative } \\
\text { illustrations }\end{array}$ & $\begin{array}{l}\text { Similar } \\
\text { illustrations, } \\
\text { Opposite } \\
\text { illustrations }\end{array}$ & $\begin{array}{l}\text { Supplementary } \\
\text { opposition }\end{array}$ & $\begin{array}{l}\text { Increasing and } \\
\text { decreasing } \\
\text { light, farness } \\
\text { and nearness of } \\
\text { lines, using dark } \\
\text { and light colors }\end{array}$ & Density of lines & $\begin{array}{l}\text { Contradicting } \\
\text { opposition }\end{array}$ \\
\hline $\begin{array}{l}\text { Directions to } \\
\text { right and left }\end{array}$ & $\begin{array}{l}\text { Opposite } \\
\text { illustrations }\end{array}$ & $\begin{array}{l}\text { Directional, } \\
\text { linear, and } \\
\text { diagonal } \\
\text { opposition }\end{array}$ & $\begin{array}{l}\text { Increasing and } \\
\text { decreasing } \\
\text { light, farness } \\
\text { and nearness of } \\
\text { lines, using dark } \\
\text { and light colors }\end{array}$ & $\begin{array}{l}\text { Change in } \\
\text { density and } \\
\text { composition of } \\
\text { lines }\end{array}$ & $\begin{array}{l}\text { Supplementary } \\
\text { opposition }\end{array}$ \\
\hline $\begin{array}{l}\text { Surface and } \\
\text { volume in } \\
\text { illustration }\end{array}$ & $\begin{array}{l}\text { Opposite } \\
\text { illustrations }\end{array}$ & $\begin{array}{l}\text { Supplementary } \\
\text { opposition }\end{array}$ & $\begin{array}{l}\text { Increasing and } \\
\text { decreasing } \\
\text { light, farness } \\
\text { and nearness of } \\
\text { lines, using dark } \\
\text { and light colors }\end{array}$ & $\begin{array}{l}\text { Change in } \\
\text { density and } \\
\text { composition of } \\
\text { lines }\end{array}$ & $\begin{array}{l}\text { Supplementary } \\
\text { opposition }\end{array}$ \\
\hline
\end{tabular}


Table 2: types of binary oppositions of Day and Night painting by Escher. part 2 (source: author)

\begin{tabular}{|c|c|c|c|c|c|}
\hline \multirow[b]{2}{*}{$\begin{array}{l}\text { Binary } \\
\text { oppositions } \\
\text { of day and } \\
\text { night of } \\
\text { Escher }\end{array}$} & \multicolumn{5}{|c|}{ Types of binary oppositions of Day and Night of Escher } \\
\hline & $\begin{array}{l}\text { direction } \\
\text { opposition }\end{array}$ & $\begin{array}{l}\text { positive and } \\
\text { negative meaning } \\
\text { opposition }\end{array}$ & whole and part opposition & $\begin{array}{l}\text { vertical and } \\
\text { horizontal, } \\
\text { diagonal and } \\
\text { crossover lines }\end{array}$ & $\begin{array}{l}\text { rhythm } \\
\text { opposition }\end{array}$ \\
\hline Day and night & $\begin{array}{l}\text { Opposition } \\
\text { to left and } \\
\text { right }\end{array}$ & $\begin{array}{l}\text { Night parts with } \\
\text { positive space, } \\
\text { day parts with } \\
\text { negative meaning }\end{array}$ & $\begin{array}{l}\text { Birds have reached from } \\
\text { whole to part; illustrations } \\
\text { of ground cubes have begun } \\
\text { from whole and ended to } \\
\text { details of birds. Rivers and } \\
\text { the sky have begun from } \\
\text { details and have been } \\
\text { represented generally in } \\
\text { horizon }\end{array}$ & $\begin{array}{l}\text { Opposition } \\
\text { of Vertical, } \\
\text { horizontal, } \\
\text { diagonal, and } \\
\text { crossover lines } \\
\text { in both pairs of } \\
\text { days and nights }\end{array}$ & $\begin{array}{l}\text { uniform rhythm } \\
\text { opposition, } \\
\text { evolutionary } \\
\text { repetition rhythm } \\
\text { opposition, wave } \\
\text { rhythm opposition }\end{array}$ \\
\hline $\begin{array}{l}\text { black and } \\
\text { white }\end{array}$ & $\begin{array}{l}\text { Opposition } \\
\text { to left } \\
\text { and right, } \\
\text { opposition } \\
\text { of directions } \\
\text { of crossover } \\
\text { and oblique } \\
\text { lines }\end{array}$ & $\begin{array}{l}\text { Black parts with } \\
\text { positive space } \\
\text { and white parts } \\
\text { with negative } \\
\text { space }\end{array}$ & $\begin{array}{l}\text { Emphasized opposition with } \\
\text { color on details such as the } \\
\text { picture of birds in whole } \\
\text { picture }\end{array}$ & $\begin{array}{l}\text { Crossover lines } \\
\text { opposition }\end{array}$ & $\begin{array}{l}\text { uniform rhythm } \\
\text { opposition, } \\
\text { evolutionary } \\
\text { repetition rhythm } \\
\text { opposition, wave } \\
\text { rhythm opposition }\end{array}$ \\
\hline Sky and earth & $\begin{array}{l}\text { Up and } \\
\text { down } \\
\text { opposition }\end{array}$ & $\begin{array}{l}\text { Day sky with } \\
\text { negative space; } \\
\text { night ground with } \\
\text { positive space; } \\
\text { night sky with } \\
\text { positive space } \\
\text { and day ground } \\
\text { with negative } \\
\text { space }\end{array}$ & $\begin{array}{l}\text { The ground parts as a part } \\
\text { of whole material world; } \\
\text { white and black birds as a } \\
\text { part of sky and the spiritual } \\
\text { world }\end{array}$ & $\begin{array}{l}\text { Opposition } \\
\text { of vertical, } \\
\text { diagonal, and } \\
\text { horizontal lines }\end{array}$ & $\begin{array}{l}\text { Uniform rhythm } \\
\text { opposition }\end{array}$ \\
\hline $\begin{array}{l}\text { Positive and } \\
\text { negative } \\
\text { illustrations }\end{array}$ & $\begin{array}{l}\text { Left and } \\
\text { right } \\
\text { opposition }\end{array}$ & $\begin{array}{l}\text { Positive } \\
\text { illustrations } \\
\text { encompass } \\
\text { positive space; } \\
\text { negative } \\
\text { illustrations } \\
\text { encompass } \\
\text { negative space }\end{array}$ & $\begin{array}{l}\text { The illustration of emphasis } \\
\text { of birds from whole to } \\
\text { part; ending emphasizing } \\
\text { illustrations of movement } \\
\text { of rivers from whole in } \\
\text { down to part in upper part } \\
\text { of the image }\end{array}$ & $\begin{array}{l}\text { Opposition } \\
\text { of vertical, } \\
\text { horizontal, and } \\
\text { diagonal lines }\end{array}$ & $\begin{array}{l}\text { uniform rhythm } \\
\text { opposition, } \\
\text { evolutionary } \\
\text { repetition rhythm } \\
\text { opposition, wave } \\
\text { rhythm opposition }\end{array}$ \\
\hline $\begin{array}{l}\text { Moving } \\
\text { directions to } \\
\text { right and left }\end{array}$ & $\begin{array}{l}\text { Left and } \\
\text { right } \\
\text { opposition }\end{array}$ & $\begin{array}{l}\text { Right hand } \\
\text { illustrations with } \\
\text { positive space } \\
\text { and left side } \\
\text { illustrations with } \\
\text { negative space }\end{array}$ & $\begin{array}{l}\text { Emphasizing illustration of } \\
\text { birds from whole to part }\end{array}$ & $\begin{array}{l}\text { Opposition } \\
\text { of vertical, } \\
\text { horizontal, } \\
\text { diagonal, and } \\
\text { crossover lines }\end{array}$ & $\begin{array}{l}\text { uniform rhythm } \\
\text { opposition, } \\
\text { evolutionary } \\
\text { repetition rhythm } \\
\text { opposition, wave } \\
\text { rhythm opposition }\end{array}$ \\
\hline $\begin{array}{l}\text { Surface and } \\
\text { volume in } \\
\text { illustration }\end{array}$ & $\begin{array}{l}\text { Growing } \\
\text { opposition } \\
\text { to up and } \\
\text { down }\end{array}$ & $\begin{array}{l}\text { Volumes with } \\
\text { positive space } \\
\text { and surfaces } \\
\text { with negative } \\
\text { space }\end{array}$ & $\begin{array}{l}\text { Existing volumes in work as } \\
\text { a part of whole of surfaces } \\
\text { of the image }\end{array}$ & $\begin{array}{l}\text { Opposition } \\
\text { of vertical, } \\
\text { horizontal, } \\
\text { diagonal, and } \\
\text { crossover lines }\end{array}$ & $\begin{array}{l}\text { uniform rhythm } \\
\text { opposition, } \\
\text { evolutionary } \\
\text { repetition rhythm } \\
\text { opposition, } \\
\text { wave rhythm } \\
\text { opposition }\end{array}$ \\
\hline
\end{tabular}


Table 3: binary oppositions of Escher's Day and Night based on performance features (source: author)

\begin{tabular}{c} 
Types of binary oppositions of Escher's Day and Night \\
\hline Continuity and discretion binary opposition \\
\hline Absence making and presence making binary opposition \\
\hline Contraction and expansion binary opposition \\
\hline Unity and dispersion binary opposition \\
\hline Summarizing and exaggeration binary opposition \\
\hline active and calm binary opposition \\
\hline Implicit and explicit binary opposition \\
\hline Impartiality and emphasis binary opposition \\
\hline Binary opposition of agreement with reality and deviation from reality \\
\hline Single-elemental and multi-elemental binary opposition \\
\hline Clear and fade binary opposition \\
\hline Validity binary oppositions \\
\hline
\end{tabular}

\section{CONCLUSION}

The results obtained from this study showed that an artistic work has wide visual opposition of signs. Signs in a visual art are in fact illustrations of an image and provide endless representation with proliferation of their meanings. The meanings of signs move in indeterminacy position with no ending, since various meanings can be derived from that, depending on the audiences and the situation of the society in any time where each of them can be a sign for another signifier.

Signs in case of binary oppositions in a visual art, in addition to explicit and real meaning, have implied and abstract meanings that are categorized under semiotics. Also in content and validity performance, the audience continuously faces illustrations with countless signs, and binary oppositions of an artistic work are caused by functions of different semiotic systems appeared in different layers of the illustrations. Hence, opposite illustrations of a visual art have open concept whose meaning creation is continuing to the end. Moreover, the analysis of binary oppositions in semiotics of visual arts can be done by analysis of illustrations where no sign can be analyzed in isolation.

The important point of this discussion concerns with the existence of binary oppositions in the nature of visual elements and visual qualities of Escher's Day and Night first, and the formal and content opposition in this work then. Illustrated binary oppositions in Day and Night are the result of a logical melody in work, which connects different parts of the painting with their unity in form of hidden connections. This can finally improve the composition of this work. They are equal 
at the same time with their opposition, and no pole is preferred to another one, and an eye-catching opposition is created, which has found new language, a careful and intelligent achievement of the artist and has created an endless chain in meaning of the work. At the same time with its simplicity, this work has applied the most underlying feature of visual art that is binary oppositions, in the best way possible. This can show the dominance of the artist on foundations of visual language and shows that no one of the poles of the oppositions are preferred to another one. These are indeed derived from the special thinking of the artist.

The painting shows companionship of day and night on the earth, which are mixed and born from each other, and the sky and the earth, which are integrated at the same time. They are opposite of each other and are released as a bird, and this is the same as life and death cycle or the same as resurrection. Black and white are the symbols of war and friendship. Other illustrations of the work, too, show uncertainty and eternity of the life and returning from the material world to the spiritual world and vice versa, resurrection and companionship of peace and war, goodness and evil, and day and night circulation. These are the effective and hidden concepts on oppositions of the illustrations in this work. With analysis of the illustrations and comparing them with binary oppositions of Derrida, a correct interpretation of the oppositions has been provided here.

\section{REFERENGES}

Ahmadi, Babak, (1992). Structure and Text Rewriting. Tehran: Center, 2 vols.

Asher, R.E; Simpson, J M.Y. (1994). The Encyclopedia of language and linguistics. Oxford; New York: Pergamon Press, vol. 1.

Bradley, A. (2008). Derrida's of Grammatology. Edinburgh: Edinburgh University Press.

Brannigan, J. (1999). 'We have Nothing to do with Literature': Jacques Derrida and Surrealist Writing. In: Brannigan J.; Robbins, R. and Wolfreys, J. (eds.). The French connections of Jacques Derrida. New York: State University of New York Press, pp. 53-70.

Chandler, Daniel (2008). The Basics of Semiotics. Translation by Mehdi Parsa, Tehran: Sureh Mehr.

Dandis, Donis A. (2016). Foundation of Visual Literacy. $44^{\circ}$ ed. Tehran: Soroush.

Daryab, Sahar (2010), One Thousand and One Nights Review by Jacques Derrida. Master's Degree in Literature. Allameh Tabatabai University, Faculty of Literature and Foreign Languages.

Derrida, J. (1982). Margins of Philosophy. Translate by Alan Bass. Brighton, Sussex UK: Harvester Press.

Derrida. J. (2005). Writing and Difference. Translate by Alan Bass. New York: Routledge. 
Escher, Maurits Cornelis (2010). Graphic compilation of Escher. Translation of Mohammad Reza Abdolali and Mozhgan Jajz. Tehran: Mirdashti.

Gharib, Rose (1999). A critique of the basis of aesthetics and its impact on literary critique. Translation of Najmeh Rehi. Mashhad: Ferdowsi University of Mashhad Publishing Company.

Habibie Afrarakhti, Masoumeh (2014). Binary opposition in Al-Lail Surah. Master's thesis in Art Research, Al-Zahra University, Faculty of Arts.

Haling Dill, Reginald John (2008). History of Western Philosophy. Translation by Abdolhossein Adazung va ed. Tehran: Ghoghnoos

Houle, Kelly M, (1998). Portrait of Escher: Behind the Mirror. In: Schattschneider, D. and

Emmer, M. (eds.). M.C. Escher's Legacy: The Centennial \& Celebration. 2nd printing. Berlin: Springer.

Lyons, John (1981). Semantics. Cambridge: Cambridge University Press, v.1.

Maghdadi, Bahram (1999). Dictionary of literary criticism (from Plato to the present). 1st print. Tehran: Fekr-e Emruz

Mousavilar, Ashraf-al-sadat; Pour Mahmoud. Sadaf (2019). A Comparative Study of Derrida's Binary Opposition Theory in Visual Arts. Lumen Publishing Jornals, vol.10. No.02.

Noroozi Talab, Hamid Reza, Ensieh Rostami Sani (2012). The deception of visualizes in the works of modernist illustrators. Two quarterly articles of Shoushtar University of Art, Shahid Chamran University of Ahvaz, No. 2, pp. 83-99.

Rahbarnia, Zahra; Motahare, Saraj (2019). Negative space messaging in the poster. Honar - Ha-Ye-Ziba Honar-Ha-Ye-Tajassomi (Journal of Fine Arts - Visual Arts), n. 24, pp. 117-124. DOI: https://dx.doi.org/10.22059/jfava.2019.69820

Scholeszer, Robert (2004). An Introduction to Structuralism in Literature. Translated by Farzaneh Taheri. Second Edition. Tehran: Agah

Shamsia, Siros (2004). Literary criticism. Fourth edition. Tehran: Ferdows.

Sojoudi F. (2012). Articles of the first contemplation of semiotics of art with layered semiotics and its application in the analysis of artistic text. 2nd edition. Tehran: Art Academy

Sojudi, Farzan (2003). Applied Semitics. Tehran: Story.

Teuber. M. (1974). Sources of ambiguity in the prints of M. C. Escher, scientific American.

Zaimran, Mohammad (2000). Jacques Derrida and Metaphysics of Presence. Tehran: Hermes.

Zibakalam, Fatima (1999). The Philosophical Thought of the West. Tehran: Publishing \& Printing Institute. 
